\title{
Clinical Event End Date Time
}

National Cancer Institute

\section{Source}

National Cancer Institute. Clinical Event End Date Time. NCI Thesaurus. Code C87841.

The date and time a clinical event has concluded. 